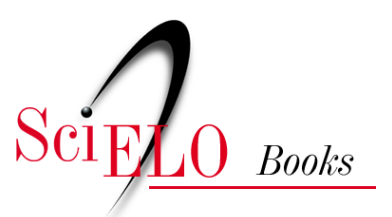

\title{
25 Tribo Bahieae B.G. Baldwin
}

\author{
João Bernardo de A. Bringel Jr. \\ Maria Alves \\ Mara Angelina Galvão Magenta
}

BRINGEL JR., J.B.A., ALVES, M., and MAGENTA, M.A.G. Tribo Bahieae B.G. Baldwin. In: ROQUE, N. TELES, A.M., and NAKAJIMA, J.N., comp. A família Asteraceae no Brasil: classificação e diversidade [online]. Salvador: EDUFBA, 2017, pp. 181-183. ISBN: 978-85-232-1999-4.

https://doi.org/10.7476/9788523219994.0027.

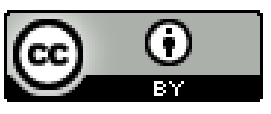

All the contents of this work, except where otherwise noted, is licensed under a Creative Commons Attribution 4.0 $\underline{\text { International license. }}$

Todo o conteúdo deste trabalho, exceto quando houver ressalva, é publicado sob a licença Creative Commons Atribição $\underline{4.0}$. 


\section{TRIBO BAHIEAE B.G. BALDWIN}

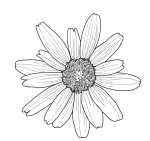

João Bernardo de A. BringelJr.

Maria Alves

Mara Angelina Galvão Magenta

Stuessy (1977) redelimitou a subtribo Bahiinae da tribo Heliantheae na tentativa de reconhecer um grupo natural. Seu conceito de Bahiinae englobava 11 gêneros, dos quais apenas 2 não estão inseridos na atual tribo Bahieae (BALDWIN, 2009; BALDWIN; WESSA; PANERO, 2002, PANERO, 2007). Tratamentos sistemáticos subsequentes ao de Stuessy (1977) para as tribos Heliantheae-Helenieae não consideraram Bahiinae como subtribo formal (KARIS; RYDING 1994, ROBINSON,1981). Apesar disso, Robinson (1981) reconheceu, dentro da subtribo Chaenactidinae, um grupo informal composto por 9 gêneros, que apresentam, em sua maior parte, células do endotécio curtas, dispostas em linhas regulares e com paredes transversais bem definidas. Todos esses gêneros estão atualmente inseridos em Bahieae (BALDWIN, 2009, PANERO, 2007), que teve seu reconhecimento consolidado como tribo a partir de estudos filogenéticos com dados moleculares de DNA (BALDWIN; WESSA; PANERO, 2002, PANERO; FUNK, 2002).

A maioria dos gêneros de Bahieae apresenta receptáculo epaleáceo, tricomas glandulares no apêndice do conectivo das anteras e corola, e cipselas de paredes estriadas (PANERO, 2007). A tribo também é bem caracterizada pela morfologia do pápus, que pode apresentar escamas com uma nervura central e a base espessada ou também cerdas ou aristas fasciculadas, às vezes de ápice uncinado (BALDWIN, 2009).

Bahieae está representada por 20 gêneros e 83 espécies, sendo a maioria distribuída na porção sudoeste dos Estados Unidos até a parte central 
do México (BALDWIN, 2009; PANERO, 2007). Poucos gêneros ocorrem na América do Sul e Índias Ocidentais (PANERO, 2007). Os únicos gêneros não americanos aceitos em Bahieae são Apostates N. S. Lander, endêmico da Polinésia Francesa, e Hypericophyllum Steetz, encontrado na África tropical, o que sugere eventos de longa dispersão (BALDWIN, 2009; PANERO, 2007).

\section{Descrição}

Ervas anuais a perenes, raramente arbustos. Folhas em rosetas ou ao longo dos ramos, alternas ou opostas, pecioladas ou sésseis, lâmina inteira ou 1-4-pinada, desprovidas de cavidades secretoras. Capitulescência corimbiforme, paniculiforme, ou capítulos solitários. Capítulos radiados, heterógamos ou discoides, homógamos, raramente disciformes, heterógamos (em Thymopsis); brácteas involucrais em 1-4 séries, muito semelhantes ou desiguais, imbricadas; receptáculo convexo ou plano, geralmente epaleáceo. Flores do raio pistiladas; flores do disco bissexuais, corola 4-5-lobada, actinomorfa, raramente zigomorfa; anteras de coloração pálida, avermelhada ou arroxeada; apêndice do conectivo geralmente oval, com ou sem tricomas glandulares; células do endotécio com espessamento polarizado (1-4) ou radial; estilete de base glabra, papilosa ou pubescente, ramos obtusos a acuminados, com ou sem apêndice. Cipselas enegrecidas, subcilíndricas a obpiramidais, 4-5 costas evidentes ou inconspícuas, paredes estriadas (exceto em Hymenopappus L' Hér. e Loxothysanus B. L. Rob.); pápus formado por escamas com ou sem nervura central, ocasionalmente escamas espessadas na base, cerdas ou aristas.

No Brasil, Bahieae é representada apenas pela espécie ruderal Schkuhria pinnata (Lam.) Kuntze ex Thell., que apresenta grande variação morfológica e pode ser dividida em 3 variedades. O táxon encontrado no país é Schkuhria pinnata var. pinnata, caracterizada por apresentar flores do raio de limbo linear (2-4 mm de comprimento) e cipselas de costas esparsamente pubescentes (TURNER, 1995). Foi coletada apenas no Distrito Federal e no estado de São Paulo. 


\section{Literatura recomendada}

BALDWIN, B. G. Heliantheae alliance. In: FUNK, V. A. et al. Systematics, Evolution and Biogeography of Compositae. Vienna: IAPT, 2009. Chapt. 41, p. 689-711.

BALDWIN, B. G.; WESSA, B. L.; PANERO, J. L. Nuclear rDNA evidence for major lineages of helenoid Heliantheae. Systematic Botany, Kent, v. 27, n. 1, p. 161-198, 2002.

HEISER JR., C. B. A revision of the genus Schkuhria. Annals of the Missouri Botanical Garden, Saint Louis, v. 32, n. 3, p. 265-278, 1945.

KARIS, P. O.; RYDING, O. 1994. Tribe Helenieae. In: BREMER K. (Ed.). Asteraceae: cladistics and classification. Portland: Timber Press, 1994. p. 521-558.

PANERO, J. L. Tribe Tageteae Cass. In: KUBITZKI, K. (Ed.). The Families and Genera of Vascular Plant: v. VIII: Flowering Plants Eudicots: Asterales. Berlin: Springer-Verlag, 2007. p. 421-431.

PANERO, J. L.; FUNK, V. A. Toward a phylogenetic subfamilial classification for the Compositae (Asteraceae). Proceedings of the Biological Society of Washington, Washington, v. 115, n. 4, p. 909-922, 2002.

ROBINSON, H. A revision of the tribal and subtribal limits of the Heliantheae (Asteraceae). Washington: Smithsonian Institution Press, 1981.

(Smithsonian Contributions to Botany, v. 51).

STUESSY, T. F. Heliantheae: systematic review. In: : HEYWOOD, V. H.; HARBONE, J. B.; TURNER, B. L. (Ed.). The Biology and Chemestry of the Composite.London: Academic Press, 1977. p. 621-671.

TURNER, B. L. Taxonomy and nomenclature of Schkuhria pinnata (Asteraceae, Helenieae). Phytologia, Huntsville, v. 79, p. 364-368, 1995. 